\title{
Integrasi Kreativitas dan Inovasi pada Kompetensi Kewirausahaan Kepala Sekolah dalam Meningkatkan Pendapatan Unit Produksi
}

\author{
Sitti Roskina Mas \\ Jurusan Manajemen Pendidikan Universitas Negeri Gorontalo \\ Jalan Jend. Sudirman No 6 Kota Gorontalo \\ sittiroskina@ung.ac.id
}

Article received: June 2020; revised: July 2020 ; accepted : August 2020

DOI : 10.17977/um025v4i32020p267

\begin{abstract}
This study aims at finding out (1) creativity and innovation of school principal in increasing income generating production units. (2) school principal motivation in increasing the production unit, and (3) and strategies of school principal in developing income generating of production unit. This research is a quantitative study with descriptive explanatory approach. The data collection methods are quentionnaire, interview, and observation. Data analisys technique is decscriptive analisys using percentage for each quasionnaire items. This study show that: (1) creativity and innovation of the school principal in increasing the income generating unit production is good category, (2) motivation of the school principal in increasing the income of income generating production unit in school is high category, and (3) strategy in increasing the income generating production unit is good category.
\end{abstract}

Keywords : creativity and innovation; entrepreneurship, income generating; production unit

\begin{abstract}
Abstrak: Penelitian ini bertujuan untuk mengetahui (1) kreativitas dan inovasi kepala sekolah dalam meningkatkan pendapatan unit produksi. (2) motivasi kepala sekolah dalam meningkatkan pendapatan unit produksi, dan (3) strategi kepala sekolah dalam meningkatkan pendapatan unit produksi di SMKN 4 Kota Gorontalo. Penelitian ini menggunakan pendekatan kuantitatif dengan jenis deskriptif eksplanatori. Tehnik pengumpulan data menggunakan angket tertutup, wawancara dan observasi. Tehnik analisis data yang digunakan adalah tehnik analisis deskriptif, setiap pertanyaan yang digunakan adalah perhitungan dengan formula presentase. Hasil penelitian menunjukkan bahwa (1) kreativitas dan inovasi kepala sekolah dalam meningkatkan pendapatan unit produksi berada pada kategori baik, (2) motivasi kepala sekolah dalam meningkatkan pendapatan unit produksi berada pada kategori tinggi, dan (3) strategi kepala sekolah dalam meningkatkan pendapatan unit produksi berada pada kategori baik.
\end{abstract}

Kata Kunci: kreativitas dan inovasi; kewirausahaan; pendapatan; unit produksi

Kepala sekolah merupakan salah satu komponen pendidikan yang paling berperan dalam meningkatkan kualitas pendidikan. Tugas kepala sekolah adalah sebagai saluran komunikasi, bertanggung jawab dan mempertanggungjawabkan, kemampuan menghadapi persoalan, berfikir analitik dan konsepsional. Profesionalitas kepala sekolah dapat tercapai apabila sudah memenuhi syarat dan kriteria tertentu sebagaimana ditetapkan dalam Peraturan Menteri Pendidikan Nasional Nomor 13 tahun 2007 tentang standar kepala sekolah yang terdiri atas kualifikasi dan kompetensi kepala sekolah.

Salah satu kompetensi yang harus dimiliki kepala sekolah adalah kompetensi kewirausahaan yang terdiri (1) menciptakan inovasi yang berguna bagi pengembangan sekolah, (2) bekerja keras untuk mencapai keberhasilan sekolah sebagai organisasi pembelajar yang efektif, (3) memiliki motivasi yang kuat untuk sukses dalam melaksanakan tugas pokok dan fungsinya sebagai pemimpin satuan pendidikan, (4) pantang menyerah dan selalu mencari solusi terbaik dalam menghadapi kendala yang dihadapi 
sekolah, dan (5) memiliki naluri kewirausahaan dalam mengelola kegiatan produksi/jasa sekolah/ madrasah sebagai sumber belajar peserta didik. Semua karakteristik tersebut bermanfaat bagi kepala sekolah dalam mengembangkan sekolah, mencapai keberhasilan, melaksanakan tugas pokok dan fungsi, menghadapi kendala sekolah, dan mengelola kegiatan sekolah sebagai sumber belajar siswa (Permen Diknas Nomor 13 Tahun 2007). Untuk menjadi seorang wirausaha diperlukan beberapa keterampilan sebagai berikut: (1) keterampilan berfikir kreatif, (2) keterampilan dalam membuat keputusan (3) keterampilan dalam kepemimpinan, (4) keterampilan manajerial, dan (5) keterampilan dalam bergaul antar manusia (Soemanto, 1996).

Salah satu kegiatan kepala sekolah adalah mengelola unit produksi secara profesional agar dapat meningkatkan income generating melalui usaha-usaha komersial, baik melalui usaha di dalam sekolah, maupun usaha komersial diluar sekolah sebagai pemilik atau pemegang saham. Untuk menjual program sekolah ataupun menawarkan produk dan jasa dibutuhkan kepala sekolah yang berjiwa entrepreneurship dan kemampuan mengembangkan tim manajemen dalam memperoleh peluang kerjasama dengan berbagai pihak dalam pengembangan unit produksi berupa penanaman modal, kerjasama pemasaran, dan peluan-peluang lainnya.

Unit produksi merupakan salah satu alternatif tempat pelatihan bagi siswa, disamping laboratorium dan industri mitra sekolah, karena dipandang dapat memberikan kontribusi yang nyata dalam melatih keterampilan dan kecakapan hidup di samping fungsi ekonomis yang dapat diberikannya. Hal ini sesuai dengan kebijakan Dikmenjur (2007); Syamwil (2010) mengatakan bahwa unit produksi merupakan fasilitas yang diberikan kepada SMK dengan tujuan untuk meningkatkan kegiatan praktik pendidikan dan pelatihan yang berorientasi pada dunia kerja.

Direktorat Pembinaan SMK (2006) menyatakan fungsi unit produksi SMK secara rinci adalah (1) sebagai sub sistem dalam sistem sekolah yang melaksanakan peningkatan keterampilan, kreatifitas, serta profesionalisme guru dan mutu tamatan, (2) wadah inovasi pengembangan kurikulum muatan lokal, (3) tempat pelaksanaan uji kompetensi dan penyusunan standar kemampuan dasar produktif, (4) pendukung pengembangan dan perawatan peralatan serta fasilitas sekolah lainnya, (5) pendukung peningkatan kesejahteraan warga sekolah, dan (6) menjadi sarana promosi sekolah dan bentuk upaya membangun citra SMK.

Untuk mencapai tujuan unit produksi tersebut salah satu faktor yang paling menentukan adalah kemampuan kepala sekolah mengembangkan jiwa (naluri) kewirausahaannya pada pengelolaan unit produksi sekolah. Dalam hal ini kewirausahaan kepala sekolah dimaknai untuk kepentingan pendidikan yang bersifat sosial bukan untuk kepentingan bisnis yang mengkomersialkan sekolah.

Kewirausahaan dalam bidang pendidikan yang diambil adalah karakteristiknya seperti inovatif, bekerja keras, motivasi yang kuat, pantang menyerah,kreatif, pandai mencari solusi terbaik, dan memiliki naluri kewirausahaan. Mendiknas (2010); Mas (2014) menyatakan kewirausahaan bukan hanya dimiliki oleh pebisnis, tetapi juga mutlak dimiliki oleh semua pekerja terutama kepala sekolah yang memang dituntut memiliki kewirausahaan yang memadai. Kemampuan kepala sekolah mengembangkan karakter kewirausahaan tersebut akan menunjukkan keberhasilan sekolah dalam mewujudkan pengelolaan sekolah yang baik.

Kompetensi kewirausahaan bagi kepala SMK sangat penting dibandingkan dengan kepala sekolah lainnya, karena salah satu tujuan SMK adalah untuk menghasilkan lulusan yang siap kerja dan mampu berwirausaha di level menengah sesuai kompetensi yang dimilikinya. Untuk itu SMK diberikan satu wadah kewirausahaan dalam bentuk lembaga usaha yaitu unit produksi sebagai incorporated entrepreneur yang harus di kelolah secara profesional. Untuk itu kepala sekolah dituntut memiliki kompetensi kewirausahaan yang baik agar dapat mengoptimalkan pendapatan (income generating) unit produksi sekolah sehingga dapat memberikan nilai tambah bagi sekolah. Beberapa SMK terutama di kota-kota besar telah menunjukkan eksistensi dalam pengelolaan unit produksi yang profesional, akan tetapi sebagian SMK belum menampakkan pengelolaan yang profesional terutama di SMK di kawasan timur Indonesia. Hal inilah yang mendasari peneliti untuk mengkaji kompetensi kewirausahaan kepala sekolah dalam meningkatkan pendapatan unit produksi sekolah di salah satu SMKN Kota Gorontalo. 
Sebelumnya peneliti telah melakukan penelitian kompetensi kewirausahaan kepala sekolah dalam mengelola unit produksi hotel pendidikan di SMKN 3 Malang, SMKN 2 Malang, dan SMKN 1 Buduran Jawa Timur (2013).

Tujuan penelitian adalah untuk mengetahui: (1) kreativitas dan inovasi kepala sekolah dalam meningkatkan pendapatan unit produksi sekolah, (2) kemampuan kepala sekolah motivasi warga sekolah untuk meningkatkan pendapatan unit produksi sekolah, dan (3) strategi kepala sekolah dalam meningkatkan pendapatan unit produksi di SMKN 4 Kota Gorontalo.

\section{METODE}

Penelitian ini menggunakan pendekatan kuantitatif, dengan jenis penelitian deskriktif eksplanatori. Penelitian ini akan mendeskripsikan kemampuan kewirausahaan kepala sekolah dalam meningkatkan pendapatan unit produksi di SMK Negeri 4 Gorontalo. Indikator yang digunakan adalah: (a) kreativitas dan inovasi, (b) kemampuan kepala sekolah motivasi warga sekolah, dan (c) strategi meningkatkan income generating unit produksi. Subjek penelitian ini adalah seluruh guru di SMKN 4 Kota Gorontalo yang berjumlah 45 orang. Penentuan subjek penelitian ini menggunakan sampling jenuh dengan semua keseluruhan jumlah digunakan sebagai populasi yang relatif kecil dari 50 orang. Jadi, semua anggota populasi dijadikan sebagai subjek penelitian.

Tehnik pengumpulan data yang digunakan adalah sebagai berikut: (1) Kuesioner tertutup, (2) wawancara, (3) observasi, dan (4) dokumentasi. Analisis data yang digunakan adalah analisis deskriptif, dengan cara memfrekuensikan masing-masing alternatif jawaban, setiap butir pernyataan dibagi jumlah informasi x 100\% yang dirumuskan sebagai berikut:

$\mathrm{Pr}=\mathrm{f} / \mathrm{n} \times 100 \%$ (Sugiyono, 2007)

\section{HASIL DAN PEMBAHASAN}

Berdasarkan hasil analisis deskripsi diperoleh data, bahwa (1) tingkat kreativitas dan inovasi pada kompetensi kewirausahaan kepala sekolah dalam meningkatkan pendapatan unit produksi sebesar $84,48 \%$, hasill penelitian ini masuk dalam ketegori baik, (2) tingkat motivasi kepala sekolah dalam meningkatkan pendapatan unit produksi sebesar $83,15 \%$ masuk dalam kategori tinggi, dan (3) tingkat prosentase strategi kepala sekolah dalam meningkatkan pendapatan unit produksi sebesar $75,11 \%$ masuk dalam kategori baik. Rekapitulasi hasil penelitian disajikan pada Tabel 1.

Tabel 1 Rekapitulasi Kemampuan Kewirausahaan Kepala Sekolah dalam Meningkatkan Pendapatan Unit Produksi di SMKN 4 Gorontalo

\begin{tabular}{|c|c|c|c|c|c|}
\hline No. & Indikator & Skor & $\begin{array}{c}\text { Persentase } \\
(\%)\end{array}$ & $\begin{array}{c}\text { Skor Ideal } \\
(\%)\end{array}$ & Kriteria \\
\hline 1 & $\begin{array}{l}\text { Kreativitas dan inovasi kepala seko- } \\
\text { lah dalam meningkatkan pendapatan } \\
\text { unit produksi di SMKN } 4 \text { Gorontalo }\end{array}$ & 190 & 84,48 & 15,51 & Baik \\
\hline 2 & $\begin{array}{l}\text { Motivasi kepala sekolah dalam me- } \\
\text { ningkatkan pendapatan unit produksi } \\
\text { di SMKN } 4 \text { Gorontalo }\end{array}$ & 187 & 83,15 & 16,84 & Tinggi \\
\hline 3 & $\begin{array}{l}\text { Strategi kepala sekolah dalam menin- } \\
\text { gkatkan pendapatan unit produksi di } \\
\text { SMKN } 4 \text { Gorontalo }\end{array}$ & 171 & 75,11 & 22,35 & Baik \\
\hline & Rata-Rata & 182,66 & 80,91 & 18,23 & Baik \\
\hline
\end{tabular}


Berdasarkan paparan hasil penelitian tersebut, dapat dimaknai bahwa kepala sekolah mampu menciptakan kreativitas dan inovasi, memotivasi warga sekolah, dan mengatur strategi dalam meningkatkan pendapatan unit produksi di SMKN 4 Gorontalo.

\section{Kreativitas dan Inovasi Kepala Sekolah dalam Meningkatkan Pendapatan Unit Produksi di SMKN 4 Gorontalo}

Hasil penelitian menunjukkan bahwa kreativitas dan inovasi kepala sekolah dalam meningkatkan pendapatan di unit produksi SMKN 4 Gorontalo berada pada kategori baik. Hal ini menunjukkan bahwa kepala sekolah mampu menciptakan keunggulam komperatif dan kompetitif untuk meningkatkan pendapatan unit produksi sekolah. Kemampuan kreatif dan inovatif ini tercermin dalam kemampuan dan kemauan kepala sekolah untuk memulai usaha (start up), kemampuan untuk mengerjakan sesuatu yang baru (creative), kemampuan untuk mencari peluang (opportunity), keberanian untuk menanggung risiko (risk bearing) dan kemampuan untuk mengembangkan ide-ide kreatif untuk menunjang pengembangan unit produksi yang efektif sebagai sumber pendapatan sekaligus sebagai sumber belajar siswa untuk meningkatkan keterampilan, kreativitas, dan mutu tamatan. Hal ini sejalan (Rusdiana, 2014: Alma, 2010; Suryana, 2006; Sony, 2011) yang mendefinisikan kreativitas sebagai kemampuan untuk mengembangkan ide-ide baru dan menemukan cara-cara baru dalam melihat masalah dan peluang. Pendapat ini didukung (Suyitno, 2014; Suyitno, 2016; Birdthistle at all, 2016; Makmur, 2015) kepala sekolah yang bermental wirausaha harus memiliki kemampuan mengembangkan kreativitas dan menciptakan inovasi yang berguna bagi pengembangan sekolah. Tidak hanya mengandalkan barang yang sudah jadi, tidak hanya menunggu instruksi dari atasan atau lainnya,harus mampu bertindak kreatif untuk mengembangkan unit produksi sekolah.

Inovasi merupakan kreasi suatu produk, jasa atau proses baru yang belum pernah dilakukan sebelumnya, inovasi yang efektif dimulai dari kecil (Sya'roni dan Sudirham, 2012). Hal yang berbeda dijelaskan oleh Rusdiana (2014) bahwa inovasi tidak lepas dari dua kriteria utama yakni kebaruan (novelty) dan perbaikan (improvement). Kebaruan disini tidak harus berupa menciptakan sebuah produk baru tapi juga bisa pada sisi nilai guna, kondisi dan aplikasinya.

Dengan demikian kreativitas merupakan sebuah proses yang dapat dikembangkan dan ditingkatkan. Kemampuan dan bakat merupakan dasarnya, tetapi pengetahuan dari lingkungannya akan mempengaruhi kreativitas seseorang. Selama ini terdapat anggapan yang keliru mengenai orang yang kreatif. Terdapat anggapan bahwa hanya orang pintar saja atau jenius saja yang memiliki kreativitas. Bahwa proses kreatif adalah proses mental yang di dalam proses itu pengalaman masa lampau dikombinasikan kembali sering dengan beberapa distorsi dalam bentuk sedemikian rupa sehingga orang muncul dengan polapola baru, konfigurasi baru, aturan baru sehingga muncul pemecahan yang lebih baik yang dibutuhkan manusia. Ini terkait dengan inovasi dimana inovasi merupakan kemampuan untuk menerapkan solusisolusi kreativ terhadap masalah dan peluang tersebut. Para entrepreneur dalam hal ini akan memiliki keberhasilan melalui kegiatan berfikir dan melaksanakan hal baru atau hal lama dengan cara-cara baru. Berfikir kreatif berhubungan dengan tindakan mengimpresi sebuah masalah secara mendalam dalam pikiran. Masalah tersebut divisualisasikan dengan jelas dan kemudian melakukan perenungan mengenai semua tindakan kearah perumusan sebuah ide atau konsep baru yang berbeda dibandingkan dengan halhal lama yang diketahui. Dengan demikian dapat disimpulkan bahwa kreativitas terletak pada aspek berfikir, sedangkan inovasi lebih menunjuk sikap dan prilaku. Sikap inovatif, terlihat dalam bentuk keberanian melakukan sesuatu yang baru dan berbeda. Seorang wirausaha harus mampu memiliki kreativitas dan inovasi karena dapat dijadikan sebagai dasar untuk menciptakan suatu produk atau jasa yang lebih kreatif, untuk dapat dimanfaatkan oleh masyarakat luas.

Dengan memanfaatkan keresahan yang sedang dialami oleh masyarakat dan kecanggihan teknologi yang sedang berkembang pesat, SMKN 4 Gorontalo mampu menjadikan peluang itu sebagai inovasi dalam berwirausaha dengan menciptakan produk dan jasa yang bernilai ekonomis dan dapat dipasarkan pada masyarakat Gorontalo dan sekitarnya untuk meningkatkan pendapatan melalui tangan-tangan dingin guru-guru produktif SMKN 4 Gorontalo. 


\section{Motivasi Kepala Sekolah dalam Meningkatkan Pendapatan Unit Produksi di SMKN 4 Gorontalo}

Motivasi menurut Rusdiana (2014) merupakan proses psikologi yang mencerminkan interaksi antara sikap, kebutuhan, persepsi, dan keputusan yang terjadi pada diri seseorang. Dengan demikian motivasi dapat dipahami sebagai keadaan dalam diri individu yang menyebabkan mereka berperilaku dengan cara menjamin tercapainya suatu tujuan. Hal ini sejalan dengan (Pramiana, 2017; Halim \& Andreani, 2017) motivasi merupakan suatu daya pendorong atau perangsang untuk melakukan sesuatu guna mencapai tujuan atau insentif tertentu.

Dengan demikian motivasi kepala sekolah melalui kompetensi yang menyentuh dimensi kewirausahaan juga berhubungan dengan dukungan aspek keuangan, kompetensi ini bisa ditunjukkan oleh kepala sekolah khususnya dalam menyiapkan anggaran pendapatan dan belanja sekolah serta mengembangkan kegiatan sekolah yang berorientasi pada aktivitas income generating.

Menurut Budiharjo, dkk (2015) kegiatan mencari pendapatan (income generating activities) adalah kegiatan-kegiatan yang mendatangkan atau meningkatkan pendapatan melalui tiga cara. Pertama, kegiatan ini tidak selalu berarti uang langsung diperoleh, namun pada proses akhirnya uang digunakan sebagai ukuran nilai barang atau jasa yang ditawarkan. Kedua, memberikan jasa bagi orang lain yang menggunakan ketrampilannya. Ketiga, dengan menggunakan sumber daya yang ada, misalnya mengerjakan sepetak tanah dan menanam tanaman untuk dijual.

Tujuan program income generating adalah untuk memperoleh pendapatan atau untuk meningkatkan penghasilan dengan pembentukan small bussiness dan dapat juga dengan menyediakan pelatihan dan pembimbingan. Lembaga-lembaga milik pemerintah selayaknya diberi kebebasan untuk melakukan kegiatan-kegiatan yang mendatangkan penghasilan (income generating activities) sehingga sumber keuangan tidak semata-mata tergantung pada pemerintah.

Dalam kewirausahaan pasti akan mengalami pasang surut dalam pemasaran hal ini akan menguji mental dari guru-guru produktif dalam menciptakan sebuah kreatifitas yang baru dan tentu saja sebagian besar di dominasi oleh rasa keputusasahaan dan ketidakberdayaan. Oleh karena itu Kepala sekolah SMKN 4 Gorontalo selalu memberikan motivasi kepada warga sekolah terutama guru-guru produktif tujuannya agar rasa kepercayaan diri tidak mudah hilang dan semangat dalam menciptakan dan memberikan hasil yang terbaik tetap dimiliki oleh guru-guru produktif. Dengan berbekal motivasi dan kepercayaan dari kepala sekolah biasanya guru-guru produktif menerapkan motivasi dalam hal bekerja lebih keras dalam menghasilkan sebuah kreativitas atau menciptakan terobosan baru yang dapat diterima oleh masyarakat. Hal inilah yang merupakan pembeda antara SMKN 4 Gorontalo dengan sekolah-sekolah lain karena SMKN 4 Gorontalo menjadikan motivasi sebagai kunci dalam membangkitkan semangat dan meraih kesuksesan dalam mengelolah unit produksi secara optimal sesuai dengan fungsi dan tujuan pendirian unit produksi di SMK sebagai sumber belajar sekaligus sebagai sumber pendapatan. Hal ini sejalan dengan (Mas, 2014) kepala sekolah harus berupaya kuat memotivasi diri untuk mencapai kesuksesan dalam kepemimpinannya dan juga memotivasi tim yang terlibat dalam manajemen unit produksi memacu untuk bekerja keras agar dapat mempertahankan prestasi yang telah dicapai, menjaga standar yang berlaku, dan bahkan mengembangkannya agar kepercayaan masyarakat dan pengguna produk unit produksi senantiasa loyal.

Peneliti menunjukkan bahwa motivasi seorang kepala sekolah sangat dibutuhkan dalam meningkatkan pendapatan unit produksi di SMKN 4 Gorontalo, karena motivasi merupakan suatu dorongan bagi seluruh siswa dan guru untuk dapat bertindak dan bertingkah laku agar dapat bekerja lebih giat lagi untuk memanfaatkan fasilitas sekolah secara optimal, menciptakan produk-produk yang baru dan yang lebih menarik agar dapat meningkatkan sumber-sumber pendapatan sekolah (income generating of school).

Dari keuntungan itu dapat dimanfaatkan untuk membantu pembiayaan pendidikan dan meningkatkan kesejahteraan bagi warga sekolah, termasuk siswa dan pengelola yang bersangkutan. Hal ini sejalan dengan Direktorat Pembinaan SMK (2006) menyatakan fungsi unit produksi SMK adalah (1) sebagai sub sistem dalam sistem sekolah yang melaksanakan peningkatan keterampilan, kreatifitas, serta 
profesionalisme guru dan mutu tamatan, (2) wadah inovasi pengembangan kurikulum muatan lokal, (3) tempat pelaksanaan uji kompetensi dan penyusunan standar kemampuan dasar produktif, (4) pendukung pengembangan dan perawatan peralatan serta fasilitas sekolah lainnya, (5) pendukung peningkatan kesejahteraan warga sekolah, dan (6) menjadi sarana promosi sekolah dan bentuk upaya membangun citra SMK.

\section{Strategi Kepala Sekolah dalam Meningkatkan Pendapatan Unit Produksi di SMKN 4 Gorontalo}

Strategi menurut teori dinamis dari Porter (dalam Rusdiana,2014) sekolah dapat mencapai keberhasilan apabila memenuhi tiga kondisi. Pertama, tujuan sekolah dan kebijakan fungsi-fungsi manajemen (seperti produk dan pemasaran) harus secara kolektif memperlihatkan posisi terkuat dipasar. Kedua, tujuan dan kebijakan tersebut ditumbuhkan berdasarkan kekuatan sekolah diperbaharui terus (dinamis) sesuai perubahan peluang dan ancaman lingkungan eksternal. Ketiga, sekolah harus memiliki dan menggali kompetensi khusus sebagai pendorong untuk menjalankan wirausaha. Hal yang berbeda dijelaskan oleh Banun, dkk (2016); Shobirin (2016) strategi adalah suatu rencana tentang pendayagunaan dan penggunaan potensi dan sarana yang ada untuk meningkatkan efektivitas dan efisiensi dalam kurun waktu tertentu.

Kepemimpinan kepala sekolah merupakan salah satu faktor yang dapat mendorong sekolah agar dapat mewujudkan visi, misi, tujuan dan sasaran sekolah melalui program-program yang dilaksanakan secara terencana dan terprogram. Dengan demikian strategi merupakan pola umum rentetan kegiatan yang harus dilakukan untuk mencapai tujuan tertentu. Kepala sekolah sebagai seorang pimpinan di suatu lembaga pendidikan perlu mempunyai strategi tertentu untuk mengembangkan motivasi pendidik dan tenaga kependidikan dilingkungan kerjanya. Kepala sekolah dilukiskan sebagai orang yang memiliki harapan tinggi bagi para staf dan para siswa. Sebagai kepala sekolah di tuntut untuk mampu melakukan sebuah perubahan dan terobosan guna peningkatan mutu dan kualitas sekolah. Hal ini sejalan dengan hasil penelitian Dahiru, dkk (2016) menyatakan bahwa kepala sekolah perlu mengembangkan model kepemimpinan kewirausahaan dalam praktek kewirausahaannnya agar dapat mencari solusi dari setiap permasalahan yang dihadapi organisasi (sekolah), memberdayakan sumber-sumber daya (potensi) yang dimiliki sekolah secara optimal agar memberikan prospek (nilai ekonomis) pada sekolah.

Hasil penelitian ini sejalan dengan (Usman, 2010) bahwa kepala sekolah sebagai seorang wirausaha, harus mampu menganalisa peluang, memanfaatkan peluang, serta menciptakan keunggulan komparatif dan kompotitif. Selain itu, harus mampu mengkondisikan dan memanfaatkan sumber daya sekolah secara produktif dan selalu berorientasi pada nilai tambah. Untuk itu diperlukan kompetensi (1) memanfaatkan dan menciptakan peluang, dan (2) mengembangkan dana dari berbagai sumber untuk menunjang operasional sekolah.

Pada saat berwirausaha sering kali para guru-guru produktif SMKN 4 Gorontalo mengalami hambatan atau kendala saat memproduksi suatu produk biasanya itu berkaitan erat dengan kerusakan alat-alat produksi atau sulitnya mendapatkan bahan-bahan baku dalam suatu daerah sehingga terkadang bahan-bahan baku tersebut harus di datangkan dari luar kota dan tentu saja harus mengeluarkan biaya yang tidak sedikit, oleh karena itu harga produk tersebut naik menjadi dua kali lipat dari biasanya dan para konsumen yang biasanya ramai membeli produk di SMKN 4 akan beralih kepada yang lain.

Untuk itu kepala sekolah bersama guru-guru produktif SMKN 4 Gorontalo berusaha untuk menemukan strategi dalam menyelesaikan masalah ini dan harus di sesuaikan dengan pertimbanganpertimbangan dari kedua tim yaitu tim produksi dan tim pemasaran. Dan dari kesepakatan tersebut kepala sekolah dan guru-guru sepakat untuk menjadikan produk tersebut sebagai produk khas Gorontalo dengan corak batik yang khas dengan daerah Gorontalo dan hanya dipamerkan event penting baik di Kota Gorontalo maupun diluar Kota Gorontalo. Karena batik ini merupakan batik khas pertama Gorontalo sehingga harganya cukup mahal karena dilihat dari proses pembuatan dan bahan-bahan baku yang digunakan berkualitas tinggi. Sehingga SMKN 4 Gorontalo dapat dinobatkan sebagai sekolah pertama 
yang mampu menciptakan Batik Khas Gorontalo dan batik krawang pertama yang ada di Gorontalo.

Berdasarkan uraian diatas menunjukkan bahwa seorang kepala sekolah harus memiliki strategi untuk dapat mengatasi setiap masalah atau kendala yang terjadi terutama masalah dalam bidang produksi dan pemasaran agar unit produksi tetap dapat dimaksimalkan sebagai sumber pendapatan sekolah (income generating of school). Pada dasarnya unit produksi merupakan miniatur yang hanya diberikan kepaada SMK yang diharapkan didalamnya ada proses kegiatan usaha (bisnis) yang dilakukan di dalam sekolah bersama warga sekolah (kepala sekolah, ketua jurusan/program, guru, dan siswa) dengan memberdayakan sumber-sumber daya sekolah yang dimiliki serta dikelola secara berkesinambungan dan profesional agar dapat menghasilkan produk dan jasa yang mendatangkan keuntungan bagi sekolah baik sebagai sumber pendapatan sekolah maupun sebagai sumber pembelajaran bagi siswa.

\section{SIMPULAN}

Kreativitas dan inovasi kepala sekolah dalam meningkatkan income generating unit produksi di SMKN 4 Kota Gorontalo berada pada kategori baik. Hal ini menunjukkan bahwa kepala sekolah mampu mempengaruhi warga sekolah untuk melakukan inovasi agar dapat memaksimalkan fungsi unit produksi sebagai pendapatan sekolah. Motivasi kepala sekolah dalam meningkatkan pendapatan unit produksi di SMKN 4 Kota Gorontalo berada pada kategori tinggi. Hal ini menunjukkan bahwa kepala sekolah mampu menggerakkan warga sekolah mengembangkan unit produksi sekolah untuk meningkatkan pendapatan sekolah.

Strategi kepala sekolah dalam meningkatkan pendapatan unit produksi di SMKN 4 Kota Gorontalo berada pada kategori baik. Hal ini menunjukkan bahwa kepala sekolah dapat mencari solusi dalam mengatasi kendala pada unit produksi agar tetap dapat dimaksimalkan sebagai sumber pendapatan sekolah.

\section{DAFTAR RUJUKAN}

Alma, Buchari. 2010. Kewirausahaan Untuk Mahasiswa dan Umum. Bandung: Alfabeta.

Banun, Sri., Yusrizal., Nasir, Usman. 2016. Strategi Kepala Sekolah dalam Meningkatkan Mutu Pendidikan pada SMP Negeri 2 Unggul Mesjid Raya Kabupaten Aceh Besar. Jurnal Administrasi Pendidikan. Volume 4. Nomor 1.

Budiharjo, Anas., Segaf., Alim, Syahirul. 2015. Pengembangan Laboratorium Mini Bank Fakultas Ekonomi Menjadi Income Generating Unit. Jurnal El-Dinar. Volume 3. Nomor 2.

Birdthistle, Naomi; Costin, Yvonne; Hynes, Briga. 2016. Engendering Entrepreneurial Competencies in the Youth of Today: A Teacher's Perspective. Education \& Training. Vol 58 No 7-8.

Dahiru, Abbas Sani and Zaidatol Akmaliah Lope Pihie. 2016. Modelling of Entrepreneurial Leadership for Effectiveness of Schools. Journal of Scientific Research. Volume 24. Nomor 4.

Direktorat Pembinaan SMK. 2006. Pengembangan Unit Produksi di SMK. Jakarta.

Dikmenjur. 2007. Pembinaan Unit Produksi/Jasa. Jakarta. Depdiknas.

Halim, Jesslyn dan Fransisca, Andreani. 2017. Analisis Pengaruh Motivasi dan Kompensasi terhadap Kinerja Karyawan di Broadway Barbershoppt Bersama Lima Putera. Jurnal Agora. Volume 5. Nomor 1.

Makmur, Agus. 2015. Efektifitas Penggunaan Metode Base Method dalam Meningkatkan Kreativitas dan Motivasi Belajar Matematika Siswa SMPN 10 Padang Sidimpuan. Jurnal EduTech. Volume 1. Nomor 1.

Peraturan Menteri Diknas. No.13 tahun 2007 tentang Kompetensi Kepala Sekolah. Jakarta: Depdiknas.

Pramiana, Omi. 2017. Motivasi Kerja dan Kinerja Karyawan Administrasi PT. BPR Pahalapakto. Jurnal Ilmiah Manajemen Fakultas Ekonomi (JIMFE). Volume 3. Nomor 2. 
Syamwil, Rosida. 2004. Optimalisasi Unit Produksi dan Unit Usaha sebagai Alternatif tempat Palatihan Keterampilan hidup dan Enterpreunerial Skill, Proceedings Konvensi Nasional Aptekinda II dan Temu Larya XIII FT/FPTK/JPTJK Universitas/IKIP se-Indonesia. Jakarta.

Mas, Sitti Roskina. 2014. The Implementation of The School Principal's Entrepreneurship Competency in The Management of Educational Hotel. International Journal Applied Business and Economic Research (IJABER). Volume 1. Nomor 4.

Rusdiana. 2014. Kewirausahaan Teori dan Praktik. Bandung, Pustaka Setia.

Shobirin, Muhammad 2016. Strategi Kepemimpinan Kepala Sekolah dalam Mengelola Sekolah Menengah Kejuruan Unggulan Nurul Islam Larangan Brebes. Journal Objective And Accurate Sources of Islamic Studies (OASIS). Volume 1. Nomor 1

Sumarsono, Sony. 2010. Kewirausahaan. Yogyakarta: Graha Ilmu.

Sugiyono. 2007. Statistika untuk Penelitian. Bandung: Alfabeta.

Suryana.2006. Kewirausahaan Pedoman Praktis, Kiat dan Proses Menuju Sukses Edisi 3. Jakarta: Salemba Empat.

Suyitno. 2014. Entrepreneurial Leadership of Vocational Schools Principals in Indonesia. International Journal of Learning \& Development. Volume 4. Nomor 1

Suyitno. 2018. Strategi Kepemimpinan Kepala Sekolah Berjiwa Wirausaha. Journal Aplikasi Administrasi. Volume 21, Nomor 2.

Soemanto Wasty.(1996). Pendidikan Wiraswasta. Jakarta:Sinar Grafika Offset.

Sya'roni, Deden A.Wahab \& Janivita, J. Sudirham. 2012. Kreativitas dan Inovasi Penentu Kompetensi Pelaku Usaha Kecil. Jurnal Manajemen Teknologi. Volume 11. Nomor 1.

Usman, Husaini. 2010. Manajemen: Teori, Praktik, dan Riset Pendidikan. Edisi 3. Jogyakarta: Bumi Aksara. 